\title{
Purinergic receptors and synaptic transmission in enteric neurons
}

\author{
Jianhua Ren • Paul P. Bertrand
}

Received: 25 May 2007 / Accepted: 6 November 2007 / Published online: 8 December 2007

(C) Springer Science + Business Media B.V. 2007

\begin{abstract}
Purines such as ATP and adenosine participate in synaptic transmission in the enteric nervous system as neurotransmitters or neuromodulators. Purinergic receptors are localized on the cell bodies or nerve terminals of different functional classes of enteric neurons and, with other receptors, form unique receptor complements. Activation of purinergic receptors can regulate neuronal activity by depolarization, by regulating intracellular calcium, or by modulating second messenger pathways. Purinergic signaling between enteric neurons plays an important role in regulating specific enteric reflexes and overall gastrointestinal function. In the present article, we review evidence for purine receptors in the enteric nervous system, including P1 (adenosine) receptors and P2 (ATP) receptors. We will explore the role they play in mediating fast and slow synaptic transmission and in presynaptic inhibition of transmission. Finally, we will examine the molecular properties of the native receptors, their signaling mechanisms, and their role in gastrointestinal pathology.
\end{abstract}

J. Ren

Neuroscience Program, Michigan State University,

East Lansing, MI 48824, USA

\section{P. P. Bertrand}

Department of Physiology and Cell Biology,

University of Nevada School of Medicine,

Reno, NV 89557, USA

Present address:

P. P. Bertrand $(\square)$

Department of Physiology, School of Medical Sciences,

University of New South Wales,

Sydney, NSW 2052, Australia

e-mail: p.bertrand@gmail.com
Keywords Adenosine receptors - Enteric nervous system . Gastrointestinal tract $\cdot \mathrm{P} 2 \mathrm{X}$ receptors $\cdot \mathrm{P} 2 \mathrm{Y}$ receptors .

Purines $\cdot$ Synaptic transmission

\begin{tabular}{|c|c|}
\hline \multicolumn{2}{|c|}{ Abbreviations } \\
\hline $\begin{array}{l}\text { 2-Me- } \\
\text { S-ATP }\end{array}$ & 2-Methylthio-ATP \\
\hline 5-HT & 5-Hydroxytryptamine or serotonin \\
\hline $\begin{array}{l}\alpha, \beta- \\
\text { m-ATP }\end{array}$ & $\alpha, \beta$-Methylene ATP \\
\hline ATP & Adenosine triphosphate \\
\hline $\mathrm{AH}$ & Afterhyperpolarization \\
\hline AHP & Afterhyperpolarizing potential \\
\hline $\begin{array}{l}\text { AH neu- } \\
\text { ron }\end{array}$ & $\begin{array}{l}\text { Type of neuron with a long-lasting AHP } \\
\text { following the action potential }\end{array}$ \\
\hline AP & Action potential \\
\hline ChAT & Choline acetyl transferase \\
\hline ENS & Enteric nervous system \\
\hline EPAN & $\begin{array}{l}\text { Extrinsic primary afferent (sensory) neuron-a } \\
\text { vagal or spinal afferent innervating the GI tract } \\
\text { with a cell body in the nodose or dorsal root } \\
\text { ganglia }\end{array}$ \\
\hline EPSP & Excitatory post-synaptic potential \\
\hline GI tract & Gastrointestinal tract \\
\hline IPAN & $\begin{array}{l}\text { Intrinsic primary afferent neuron with a cell } \\
\text { body in the wall of the gut, also called an } \\
\text { intrinsic sensory neuron }\end{array}$ \\
\hline NPY & Neuropeptide Y \\
\hline NOS & Nitric oxide synthase \\
\hline RMP & Resting membrane potential \\
\hline PPADS & $\begin{array}{l}\text { Pyridoxal phosphate-6-azopheyl-2',4'-disulphonic } \\
\text { acid }\end{array}$ \\
\hline SOM & Somatostatin \\
\hline TTX & Tetrodotoxin \\
\hline UTP & Uridine 5 '-triphosphate \\
\hline
\end{tabular}


UDP Uridine 5'-diphosphate

VIP Vasoactive intestinal peptide

\section{Introduction}

The enteric nervous system (ENS) is located in the wall of the gut and is composed of two ganglionated plexes: the myenteric plexus and submucosal plexus. The ENS regulates and coordinates the activity of the gastrointestinal (GI) tract. The neurons of the ENS are specialized for sensory, motor, and interneuronal roles and together form multiple complex circuits for driving reflexes [1]. Enteric neurons receive some synaptic inputs from the sympathetic and the parasympathetic nervous systems but receive the majority of their inputs from other enteric neurons within the ENS. Synaptic transmission in the ENS utilizes fast ligand-gated ion channels and slow G-protein-coupled receptors to transmit and process information [2, 3]. Purinergic receptors including P2X, P2Y, and adenosine receptors have been localized to neurons in the ENS. A primary role for $\mathrm{P} 2 \mathrm{X}$ receptors has been found in mediating fast synaptic transmission while $\mathrm{P} 2 \mathrm{Y}$ receptors predominately mediate slow synaptic transmission and adenosine receptors mediate presynaptic inhibition. Together, these receptors affect many enteric reflexes and motor patterns [see review in Chapter 2 of this issue, 4].

In the present article, we review the evidence for P1 and P2 receptors in the ENS and examine the role they play in mediating fast and slow synaptic transmission and in presynaptic inhibition of transmission. We will also look at the molecular properties of the native receptors, their signaling mechanisms and their role in gastrointestinal pathology. The reader is directed to other chapters in this issue for more detailed information on the role purinergic transmission plays in reflexes, and on the role of adenosine in secretion $[4,5]$.

\section{Enteric neurons}

The enteric neurons can be classified by their shape, projection pattern, electrophysiology, and their neurotransmitter or chemical content [6-9]. The neurons that use ATP or adenosine as transmitters are termed purinergic neurons. The following summarizes the major subtypes and electrophysiological properties of enteric neurons (Fig. 1), highlighting those neurons that are purinergic.

Enteric intrinsic primary afferent neurons

There are enteric neurons that are sensitive to chemical or mechanical cues from the gastrointestinal tract with cell bodies in the myenteric and submucous plexes. They are properly referred to as intrinsic primary afferent neurons (IPANs) and are separate from the extrinsic primary afferent neurons whose cell bodies are in dorsal root or nodose ganglia [10]. In this review we will simply refer to them as sensory neurons. Many enteric sensory neurons have "AH"-type electrophysiological characteristics which are defined as having an action potential afterhyperpolarization lasting $>1$ s [11-13]. Most sensory neurons have smooth cell bodies and are multipolar with projections that run to the mucosal epithelium, between the myenteric plexus and the submucosal plexus, and to their own and nearby ganglia [14]. They form synapses with all other neuronal types. To date there is no evidence that enteric sensory neurons release ATP as a neurotransmitter.

Interneurons

Enteric interneurons are primarily found in the myenteric plexus where there is generally one subtype of interneuron (two types in proximal colon) with an ascending projection and at least three subtypes of interneuron with a descending projection. There are also a small number of intestinofugal neurons that send a projection to prevertebral ganglia [1]. All interneurons have a single axon, but there is a mix of dendritic morphology. Interneurons are characterized electrophysiologically as "S" neurons, which are those neurons
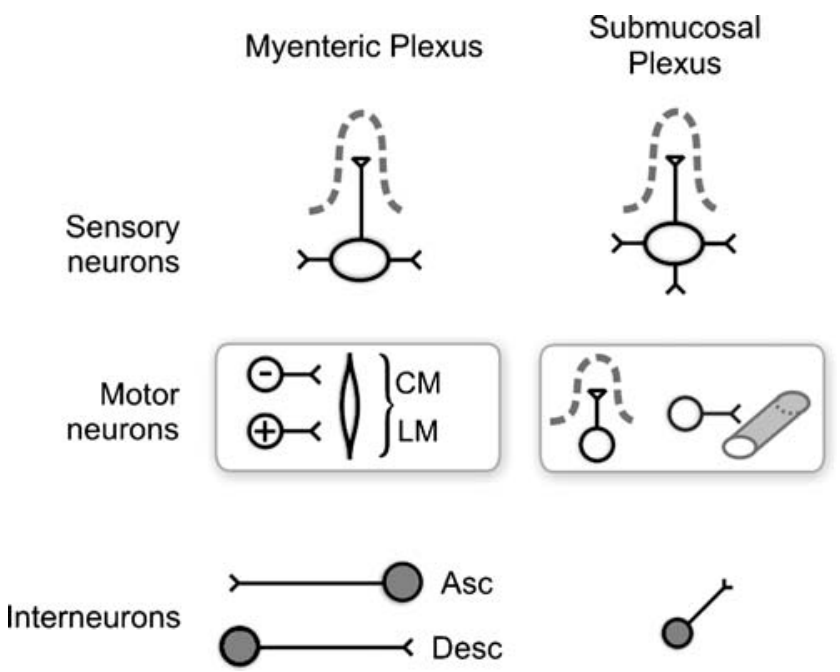

Fig. 1 Diagram showing the major functional subtypes of neuron in the enteric nervous system. The major functional types are listed on the left and the two plexes, the myenteric and the submucosal, are listed at the top. Enteric sensory neurons are found in both the myenteric and submucosal plexes. The inhibitory $(-)$ and excitatory $(+)$ motor neurons to the circular $(C M)$ and longitudinal $(L M)$ smooth muscle are only found in the myenteric plexus while secretomotor neurons and vasodilator neurons are mainly found in the submucosal plexus. Ascending $(A s c)$ and descending (Desc) interneurons are found in the myenteric plexus, while in the submucosal plexus, only a small population of local interneurons is found 
in which a single stimulus to an interganglionic nerve bundle can trigger a fast EPSP [11, 12]. They can differ in their level of excitability and in their ability to fire action potentials repetitively $[12,15,16]$. In the myenteric plexus, ATP is utilized as a transmitter or co-transmitter by at least one type of descending interneuron during local reflexes [4, 17]. These descending interneurons are immunoreactive for nitric oxide synthase (NOS) and vasoactive intestinal polypeptide (VIP) and have Dogiel type I dendrites. In the submucous plexus, interneurons comprise $<15 \%$ of the population of neurons; however, they do not appear to release ATP or adenosine as a neurotransmitter.

\section{Motor neurons}

Enteric motor neurons are found in the myenteric and submucous plexes. They have a single axon and short dendrites with Dogiel type I morphology. In the myenteric plexus, there are four functional classes of motor neuron to the smooth muscle layers of the intestine $[1,9]$ : inhibitory or excitatory motor neurons to either the circular or longitudinal smooth muscle layers. All motor neurons have S-type properties and, like the interneurons, they can differ in their level of excitability [12]. In the myenteric plexus, inhibitory motor neurons to the circular muscle are immunoreactive for NOS and VIP and use ATP as a coneurotransmitter $[1,6,18]$. In the submucous plexus, there are two types of excitatory secretomotor neurons going to the epithelium and at least one type of vasodilator neuron to the submucous arterioles. Noncholinergic secretomotor/ vasodilator neurons are immunoreactive for dynorphin, galanin, and VIP. These neurons account for $\sim 45 \%$ of submucosal neurons, and they may utilize ATP as a coneurotransmitter $[19,20]$.

\section{Purinergic receptors}

Purinergic receptors include $\mathrm{P} 1$ and $\mathrm{P} 2$ receptors that are activated by the endogenous purines, adenosine and ATP, respectively. Thus, transmission involving either receptor is called purinergic [21]. Adenosine and ATP are recognized as either neurotransmitters or neuromodulators in the central nervous system [e.g., 22], the peripheral nervous system [e.g., 23, 24] and the ENS [2, 25].

Adenosine acts through G-protein-coupled P1 receptors that are commonly referred to as adenosine receptors $\left(\mathrm{A}_{1}\right.$, $\mathrm{A}_{2}$, etc). ATP acts at both ligand-gated $\mathrm{P} 2 \mathrm{X}$ receptors/ion channels $[26,27]$ and at G-protein-coupled P2Y receptors $[28,29]$. Adenosine is thought to be liberated from cells as a consequence of metabolic stress or as a breakdown product of released ATP. In contrast, ATP is thought to be primarily released from neuronal sources as a neurotrans- mitter, although there is evidence of ATP release from nonneuronal cells such as working muscle [29].

P1 (adenosine) receptors

P1 receptors are typical G-protein-coupled receptors that act through modulation of adenylyl cyclase [21]. At least four genes for adenosine receptor subtypes have been cloned. These genes encode for $A_{1}, A_{2 A}, A_{2 B}$, and $A_{3}$ receptors. Adenosine acts as an agonist at all of these receptors with AMP and ADP showing progressively weaker interactions. ATP is not, by definition, considered an agonist at these receptors. The pharmacology of the adenosine receptors is characterized mainly by selective receptor antagonists. See Ralevic and Burnstock [21] for a full review of the P1 adenosine receptors.

\section{P2 (ATP) receptors}

P2X receptors are nonselective cation channels that open upon binding a ligand. The molecular structure of a P2X receptor is probably a trimer consisting of one or more different subunits [30]. There are seven subtypes of P2X receptor found in adult mammalian tissue, $\mathrm{P} 2 \mathrm{X}_{1-7}[27,31]$. Each subunit has two membrane-spanning domains (TM1 and TM2) and a large extracellular domain [26]. TM1 is responsible for channel gating, and TM2 forms the ion pore. The extracellular loop is suggested to be involved in binding of two molecules of ATP. Studies of heterogeneous expression of the P2X-receptor subunits have generated a series of data for the properties of different P2X subunit combinations [27]. P2X receptors can be composed of the same or different subunits to form homomers or heteromers, respectively. All P2X subunits can form homomers, except the $\mathrm{P} 2 \mathrm{X}_{6}$, which only combines with other subunits. All P2X subunits can also form heteromers, except the $\mathrm{P}_{2} \mathrm{X}_{7}$ subunit, which can only form a homomer. The specific composition of the P2X subunits determines the unique pharmacological and physiological properties of the native receptors. For example, ATP is a ligand at all P2X receptors, but the ATPanalogue $\alpha, \beta$-methylene-ATP is a more selective agonist at $\mathrm{P}_{2} \mathrm{X}_{1}$ and $\mathrm{P} 2 \mathrm{X}_{3}$ subunit containing receptors than at other subtypes, while 2-methylthio-ATP is a more selective agonist at $\mathrm{P} 2 \mathrm{X}_{2}$ and $\mathrm{P} 2 \mathrm{X}_{3}$ receptors [21].

$\mathrm{P} 2 \mathrm{Y}$ receptors are G-protein-coupled (metabotropic) receptors [29]. In mammals, there are at least eight genes encoding subtypes of $\mathrm{P} 2 \mathrm{Y}$ receptor with more likely awaiting discovery [28, 32]. The five main receptor subtypes are the $P 2 Y_{1,2,4,6,11}$. All couple to activation of phospholipase $\mathrm{C}$ and, in addition, $\mathrm{P}_{2} \mathrm{Y}_{11}$ couples positively to adenylyl cyclase. ATP is a ligand at all of these receptors, but UTP, UDP, or ADP may be more potent and can be used pharmacologically to distinguish between receptor 
subtypes [28]. Similarly, $\alpha, \beta$-methylene-ATP is not an agonist at $\mathrm{P} 2 \mathrm{Y}$ receptors, but 2-methylthio-ATP is an agonist at $\mathrm{P} 2 \mathrm{Y}_{1}$ and $\mathrm{P} 2 \mathrm{Y}_{11}$ receptors [21].

\section{Adenosine and P1 receptors in the ENS}

The production of adenosine

Many studies have shown that $P_{1}$ receptors are activated by endogenous adenosine, but whether adenosine is stored in synaptic vesicles and released as a neurotransmitter is not clear. One way adenosine may be made available is from the breakdown of released ATP. ATP is degraded by extracellular enzymes known as ectonucleotidases of which there are several classes [33]. For example, the production of adenosine from the hydrolysis of ATP released from activated smooth muscle cells has been demonstrated [34]. Adenosine may then act at its own receptors before itself being broken down to inosine by the enzyme adenosine deaminase. Studies in the ENS have failed to show an appreciable effect when ATP is applied and P1 receptors are blocked $[35,36]$ or when breakdown of ATP is prevented [37], suggesting that this route for adenosine formation, although plausible, may not be physiologically relevant.

Another route by which adenosine may be released into the extracellular space is a nonspecific release from normal cells including neurons. Electrically evoked adenosine release has been demonstrated from myenteric plexuslongitudinal muscle preparations [38]. Myenteric neurons were the main source of endogenous adenosine, since blockade of action potentials with tetrodotoxin $(1 \mu \mathrm{M})$ or omission of $\mathrm{Ca}^{2+}$ (plus EGTA, $1 \mathrm{mM}$ ) in the solution essentially abolished nucleoside release, while adenosine outflow remained unchanged when smooth muscle contractions were prevented by nifedipine [37]. Adenosine can be released under basal conditions, but its release is often increased under metabolically stressful conditions such as ischemia, inflammation, or cell damage [e.g., 39]. In the gut, endogenous concentrations of adenosine have been found to vary with the $\mathrm{pO}_{2}$ in the myenteric plexus [40].

Identification and expression of P1 subtypes in the ENS

Adenosine applied to the intestine can influence intestinal functions by directly acting at adenosine receptors on smooth muscle [41-43] or by indirectly acting at adenosine receptors in the ENS to regulate neurotransmitter release $[42,44,45]$. This evidence suggests that adenosine receptors are located within the GI tract and, thus, that endogenous adenosine may play a physiological role. For example, regulation of secretion by adenosine has been established [see Chapter 3, this issue, 5]. On the other hand, homozygous $\mathrm{A}_{1}$ adenosine receptor-null mice are viable and without gross behavioral or anatomic abnormalities [46], suggesting other receptors can compensate for the loss of the $A_{1}$ receptor.

Adenosine may mediate relaxation of the intestine through two different inhibitory receptor subtypes. In the guinea-pig distal colon, $A_{1}$ receptors are on enteric neurons and $A_{2 B}$ receptors are on the smooth muscle [41, 47]. In contrast, in murine proximal colon, $\mathrm{A}_{1}$ receptors have been identified on smooth muscle and mediate relaxation, while in distal colon, there are additionally $\mathrm{A}_{2 \mathrm{~B}}$ receptors localized on myenteric inhibitory motor neurons releasing NO [42]. In rat small intestine, the ascending and descending reflexes in the myenteric plexus are modulated by release of endogenous adenosine acting at $A_{1}$ receptors [48]. More recently, the coexistence of both inhibitory $A_{1}$ and facilitatory $\mathrm{A}_{2}$ adenosine receptors in the rat myenteric plexus has been demonstrated [49]. Finally, in the human enteric nervous system, the distribution of adenosine receptor mRNA and protein has been demonstrated [50]. The $A_{1}$ receptor is expressed in jejunal myenteric neurons and colonic submucosal neurons, while in the jejunal myenteric plexus, $A_{2 B}$ receptor immunoreactivity was found in more neurons than was the $\mathrm{A}_{2 \mathrm{~A}}$ receptor [50] [see Chapter 3, this issue, 5].

Postsynaptic P1 receptors may not mediate synaptic potentials

In the ENS, there is no clear evidence that synaptic potentials are caused by the release of adenosine acting at postsynaptic receptors. This is despite very good evidence that exogenously applied adenosine can cause a closure of potassium channels and a slow EPSP-like depolarization in some AH neurons [51]. These effects are thought to be through the $A_{2 A}$ receptor, which couples positively with adenylyl cyclase and causes accumulation of cAMP. This is supported by the finding that exogenous AMP also acts at $\mathrm{A}_{2 \mathrm{~A}}$ receptors to cause slow EPSP-like depolarizations [52]. Exogenous application of adenosine also causes a slow hyperpolarization in some $\mathrm{AH}$ neurons [53] through the $\mathrm{A}_{1}$ receptor and inhibition of adenylyl cyclase [51, 54]. Inhibition of adenylyl cyclase reduces the depolarization produced by many neuropeptides that presumably work by increasing cAMP [53, 55]. Nonetheless, there is no evidence for a slow IPSP mediated by endogenously released adenosine.

Presynaptic P1 receptors inhibit transmitter release and synaptic transmission

The most important function of adenosine in the ENS seems to be that of a modulatory substance that is present 
tonically and changes only slowly. Experiments have clearly shown that endogenous adenosine is present and can act on its own receptors [for review, see 25]. Activation of $\mathrm{A}_{1}$ receptors can cause inhibition of contraction in a TTX-insensitive manner in murine proximal and distal colon [42]. Antagonists at $A_{1}$ receptors can enhance the release of acetylcholine or tachykinins from myenteric ganglia $[44,56,57]$. This modulation is likely to be through $A_{1}$ receptors that are presynaptic. Similarly, fast EPSPs are reduced in the presence of adenosine (Fig. 2a) or AMP, an effect blocked by $A_{1}$ receptor antagonists $[51,52,54]$. The mechanism underlying presynaptic $A_{1}$ receptor inhibition of transmitter release involves an inhibition of adenylyl cyclase or phospholipase $\mathrm{C}$ with one result being an increase in potassium conductance and/or a decrease in calcium conductance [58]. Although presynaptic inhibition of transmitter release appears to be the main role of P1 adenosine receptors, there is one report that P2 ATP receptors may participate in presynaptic inhibition [36].

\section{ATP and P2 receptors in the ENS}

The source of ATP in the ENS

Localization of ATP is more difficult than localization of other substances [21]. Unlike classical transmitters or neuropeptides, purines are located throughout a cell making standard histochemical approaches nonspecific. Quinacrine staining has been used by some groups to visualize the high concentrations of ATP in vesicles [e.g. 59], although the specificity of this technique has not been well-established. In the ENS, quinacrine localization does not demonstrate unequivocally that there are ATP-containing nerve terminals

\section{a Fast EPSPs}
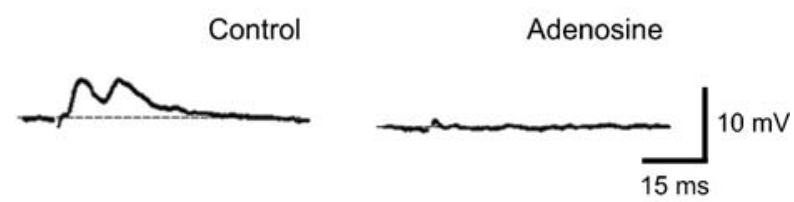

\section{b Nicotinic agonist}
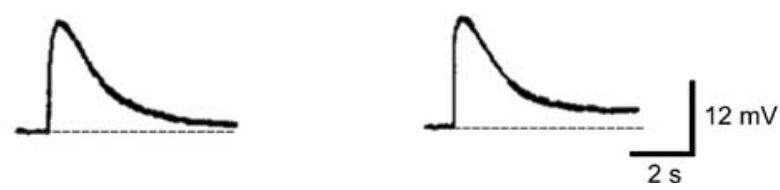

Fig. 2a, b Presynaptic inhibition of fast synaptic transmission in an $\mathrm{S}$ neuron in the submucous plexus of guinea pig ileum. a Left A fast EPSP was evoked by a single stimulus to an interganglionic fibre tract. Right Exposure to adenosine for 5 min suppressed the fast EPSP. b Left Depolarization to pressure application of DMPP $(1 \mu \mathrm{M})$. Right During blockade of the fast EPSP, the depolarization to DMPP was unchanged in the presence of adenosine. Adapted from [114]. Copyright (C) Gastroenterology or cell bodies; thus, the functional classes of neuron that might release ATP cannot be found directly.

Studies from vagal and sympathetic nerves have suggested that ATP is a co-transmitter with ACh, NE or histamine [60, 61]. In vivo, ATP released from these sources may reach and act on enteric purinergic receptors [20]. In the myenteric plexus, ATP can be released from varicosities by nicotinic-receptor agonists [62, 63]. Studies on the enteric circuitry point toward ATP being co-released from noncholinergic neurons using VIP or NO as cotransmitters [64]. This is supported by indirect evidence from the guinea pig colon that suggests ACh and ATP are not co-stored, as there is an increase in synaptic ATP release but not $\mathrm{ACh}$ release from inflamed tissue [65]. For more information on the role of ATP in the enteric circuitry see Chapter 2, this issue [4].

\section{P2X receptors mediate fast EPSPs in the ENS}

Fast EPSPs in enteric $\mathrm{S}$ neurons are short $(\sim 30 \mathrm{~ms})$, high amplitude $(>10 \mathrm{mV})$ depolarizations. A single fast EPSP can be triggered by a single presynaptic stimulus and can initiate an action potential. Fast EPSPs are the major form of communication between enteric neurons and are mainly mediated by ACh acting through nicotinic receptors. Data in the last 10 years have, however, suggested that a significant proportion of fast synaptic transmission is purinergic and that this component may be important in disease states.

\section{Properties of $P 2 X$ receptors in the ENS}

Electrophysiological characterization of $\mathrm{P} 2 \mathrm{X}$ receptors has been made in cultured guinea-pig myenteric neurons and in intact LMMP preparations. ATP-induced whole-cell currents show inward rectification. This is due to a decrease in the open probability of single channels at more positive membrane potentials as a single-channel current-voltage relationship is linear [66]. A reversal potential of $0 \mathrm{mV}$ indicates that $\mathrm{P} 2 \mathrm{X}$ receptors have a nonselective permeability to cations. Inward currents induced by ATP acting at myenteric P2X receptors desensitize by $80 \%$ in $7 \mathrm{~s}$ [66]. In guinea-pig myenteric plexus, $\mathrm{P} 2 \mathrm{X}$ receptors have also been shown to couple to a calcium-dependent conductance that mediates an afterhyperpolarization in some NOS-positive S neurons [67].

Interactions between $P 2 X$ receptors and other ligand-gated ion channels

Studies have shown that there is a functional interaction between P2X and nicotinic acetylcholine receptors [68-70]. $\mathrm{P} 2 \mathrm{X}$ receptors are co-expressed in at least $67 \%$ of 
myenteric neurons with nicotinic acetylcholine receptors. Simultaneous activation of nicotinic and P2X receptors produces a response that is smaller in amplitude than the predicted sum of responses caused by individual activation of each receptor. Recently, $\mathrm{GABA}_{\mathrm{A}}$ currents or current produced by activation of $5-\mathrm{HT}_{3}$ receptors has also been found to occlude P2X currents in much the same way [71, 72]. Taken together, these data suggest that a functional interaction between P2X and other ligand-gated channels may be the norm and thus physiologically important.

\section{Localization of $P 2 X$ receptors in the ENS}

In the guinea-pig ileum, $\mathrm{P} 2 \mathrm{X}_{2}$ receptors have been localized in the myenteric plexus to populations of NOS-positive interneurons or motor neurons, and on intrinsic sensory neurons [73]. Ninety percent of the intrinsic sensory neurons stained for the $\mathrm{P}_{2} \mathrm{X}_{2}$ receptor, with one-third of these staining strongly and the rest staining weakly. In the mouse intestine, $\mathrm{P} 2 \mathrm{X}_{2}$ receptor mRNA has been localized to a much smaller population of myenteric neurons of unknown functional class [74]. In the guinea pig, P2X receptors are found on a variety of myenteric neurons, including some NOS-positive neurons (inhibitory motor and descending interneurons) and ascending interneurons or longitudinal muscle motor neurons, but not on sensory neurons $[75,76]$. Similar data in mice have shown the presence of $\mathrm{P} 2 \mathrm{X}_{2}, \mathrm{P} 2 \mathrm{X}_{3}$, and $\mathrm{P} 2 \mathrm{X}_{5}$ receptors on many myenteric and submucosal neurons [77] although only $\mathrm{P} 2 \mathrm{X}_{2}$ receptors have subsequently been found to participate in fast synaptic transmission [78] (see below).

In the rat, Xiang and Burnstock [79] found mRNA and immunoreactivity for $\mathrm{P} 2 \mathrm{X}_{2}$ and $\mathrm{P} 2 \mathrm{X}_{3}$ receptors throughout the GI tract, from the stomach to the colon. In the myenteric plexus, $20 \%$ of $\mathrm{P} 2 \mathrm{X}_{2}$ receptors and $80 \%$ of $\mathrm{P} 2 \mathrm{X}_{3}$ receptors are localized to intrinsic sensory neurons. In the submucous plexus, intrinsic sensory neurons comprised $20 \%$ of the $\mathrm{P}_{2} \mathrm{X}_{2}$-receptor-positive neurons and $40 \%$ of the $\mathrm{P}_{2} \mathrm{X}_{3}$ receptor-positive neurons [79]. Recent data from Van Crombruggen et al. have supported this by showing that $\mathrm{P} 2 \mathrm{X}_{2}$ and $\mathrm{P} 2 \mathrm{X}_{3}$ receptors are found on nerve fibers in the myenteric and submucous plexus of rat distal colon [80].

\section{Fast synaptic transmission}

Interneurons and motor neurons (S neurons) In guinea-pig ileum, electrophysiological recordings have indicated that fast EPSPs from $67 \%$ of myenteric $\mathrm{S}$ neurons are sensitive to the P2X-receptor antagonists PPADS or suramin $[2,81]$ (Fig. 3a). The purinergic fast EPSPs are not, however, evenly distributed along the GI tract. Recordings from different segments of the gut indicate that purinergic fast EPSPs are most common in the ileum as compared with the duodenum, jejunum, taenia coli, proximal and distal colon, but are absent in gastric corpus [82, 83]. Evidence from combined electrophysiological and lesion studies have shown that some of these P2X receptors are in descending pathways [84]. These data have been extended by recent studies in the submucosal plexus of the guinea pig where P2X-mediated fast EPSPs have been identified [19] (Fig. 3b). Together these data suggest that endogenous ATP acting at P2X receptors mediates fast EPSPs between many neurons in the ENS.

Intrinsic sensory neurons (AH neurons) P2X receptors may also mediate activation of $\mathrm{AH}$ neurons and contribute to initiation of peristalsis [85]. ATP applied to the cell bodies evoked a large depolarization in most myenteric $\mathrm{AH}$ neurons that was blocked by PPADS and, unexpectedly, potentiated by suramin. Similarly, ATP applied to small areas of the mucosal epithelium activated the mucosal sensory nerve terminals of the AH neurons. PPADS blocked the activation of the nerve terminals and a $5-\mathrm{HT}_{3}$ receptor antagonist reduced it. Thus, ATP may act directly through P2X receptors on the sensory nerve terminal and through the release of serotonin from enterochromaffin cells. These data suggest that ATP participates in both the sensory transduction of stimuli from the gut lumen and in the subsequent initiation and propagation of enteric reflexes.

Although $\mathrm{P}_{2} \mathrm{X}_{2}$ receptors have been localized to $\mathrm{AH}$ neurons $[78,86]$, fast excitatory synaptic inputs are rarely recorded from these neurons in guinea pig [86] or mouse $[78,87]$. Fast EPSPs that have been recorded from sensory neurons are much smaller in amplitude than in S neurons $[12,88]$. Fast EPSPs in sensory neurons appear to be mediated by ACh acting at nicotinic receptors, but whether purines also participate is not yet clear.

Subtypes of $P 2 X$ receptor One question remaining is what subtypes of P2X receptor are responsible for fast synaptic transmission in $\mathrm{S}$ neurons and depolarization in $\mathrm{AH}$ neurons. Immunohistochemical studies have localized $\mathrm{P} 2 \mathrm{X}_{2}$ and $\mathrm{P} 2 \mathrm{X}_{3}$ subunits to some myenteric neurons in guinea pig $[73,75,76]$. Recent studies have utilized mice deficient in $\mathrm{P} 2 \mathrm{X}_{2}$ or $\mathrm{P} 2 \mathrm{X}_{3}$ receptors to investigate these subtypes in $\mathrm{S}$ and $\mathrm{AH}$ neurons $[78,89]$. S neurons in tissues from $\mathrm{P} 2 \mathrm{X}_{2}{ }^{+++}$mice were depolarized by ATP but not by $\alpha, \beta$-mATP. This result suggests that $\mathrm{S}$ neurons express $\mathrm{P} 2 \mathrm{X}_{2}$ homomeric receptors as $\alpha, \beta$-mATP does not activate $\mathrm{P} 2 \mathrm{X}_{2}$ homomers, but does activate $\mathrm{P} 2 \mathrm{X}_{3}$ homomeric and $\mathrm{P}_{2} \mathrm{X}_{2 / 3}$ heteromeric receptors $[27,90]$. ATP failed to elicit a depolarization in $\mathrm{S}$ neurons from $\mathrm{P} 2 \mathrm{X}_{2}{ }^{-/-}$mice, and fast EPSPs were not reduced by PPADS, a nonspecific P2receptor antagonist (Fig. 4a). Fast EPSPs from P2X ${ }_{3}^{--}$ mice were reduced by PPADS to a similar level as were fast 


\section{a Myenteric Plexus}

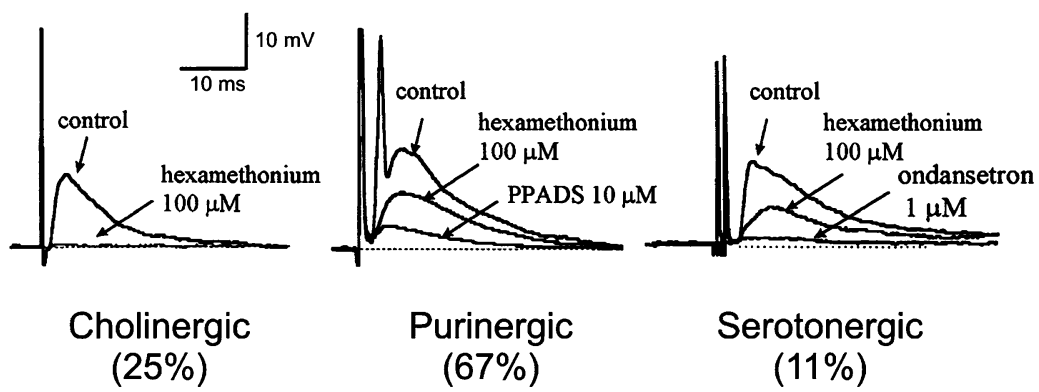

\section{b Submucosal Plexus}

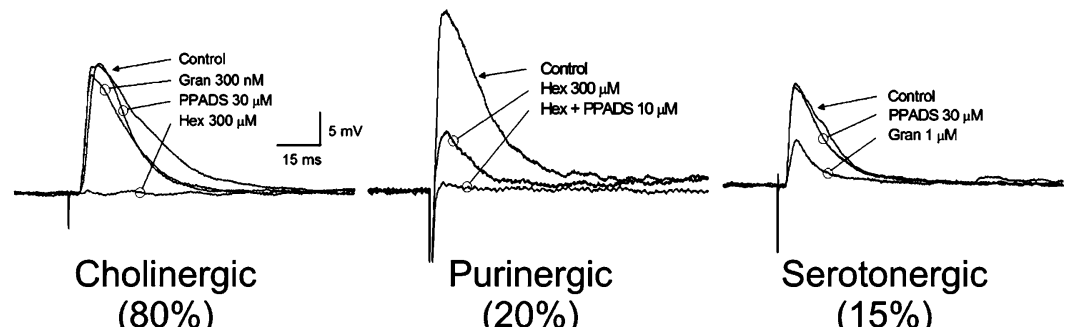

Fig. 3a, b Fast EPSPs in the myenteric and submucous plexes of the guinea pig ileum have a prominent purinergic component. a Pharmacologically distinct fast EPSPs from myenteric neurons. Left A fast EPSP that was blocked by the nicotinic-receptor antagonist hexamethonium $(100 \mu \mathrm{M})$. Middle A fast EPSP that is partly reduced by hexamethonium and the rest is blocked by PPADS, an antagonist that blocks $\mathrm{P} 2$ receptors. Right A fast EPSP that is partly reduced by hexamethonium and is completely inhibited by the subsequent addition of the 5-HT-receptor antagonist ondansetron. Adapted from
[115]. Copyright (C) Autonomic Neuroscience. b Pharmacologically distinct fast EPSPs from submucosal neurons. Left Application of the nicotinic-receptor antagonist hexamethonium $(300 \mu \mathrm{M}$, Hex) abolished this fast EPSP. Middle In this neuron hexamethonium depressed the fast EPSP, and PPADS $(10 \mu \mathrm{M})$ abolished the remainder. Right PPADS $(10 \mu \mathrm{M})$ had no effect on this fast EPSP, but granisetron depressed it by approximately 50\%. Adapted from [19]. Copyright (C) Journal of Physiology
EPSPs from $\mathrm{P} 2 \mathrm{X}_{3}{ }^{+/+}$mice (Fig. 4b). Based on these results, it was concluded that the $\mathrm{P} 2 \mathrm{X}$ receptor mediating fast EPSPs in murine $\mathrm{S}$ neurons is a $\mathrm{P} 2 \mathrm{X}_{2}$ homomeric receptor.

In a parallel study in the guinea pig ileum, all $S$ neurons that were sensitive to ATP were depolarized by $\alpha, \beta$-mATP [67] but only $17 \%$ of $\mathrm{AH}$ neurons were sensitive to $\alpha$, $\beta$-mATP (J. Ren, personal observation). Previous pharmacological studies have found that $\alpha, \beta$-mATP-sensitive P2Xreceptor subtypes $\left(\mathrm{P} 2 \mathrm{X}_{1}\right.$ or $\left.\mathrm{P} 2 \mathrm{X}_{3}\right)$ contribute to fast EPSPs [82]. TNP-ATP, a selective antagonist for $\mathrm{P}_{2} \mathrm{X}_{1}$ or $\mathrm{P} 2 \mathrm{X}_{3}$ receptors, reduced ATP-induced depolarization and reduced fast EPSP amplitude in S neurons. These results are not, however, consistent with guinea pig myenteric neurons maintained in primary culture, which do not desensitize to $\alpha, \beta$-mATP [66]. One important difference between these studies is that the cultured enteric neurons were isolated from new-born guinea pigs while the intact preparations were dissected from adults. Thus, the differences seen could be caused by a switch from one P2X-receptor subtype to another during development. In support of this idea it has been shown in the rat stomach that the levels of $\mathrm{P} 2 \mathrm{X}_{3}$ receptor expression undergo developmental changes [91].

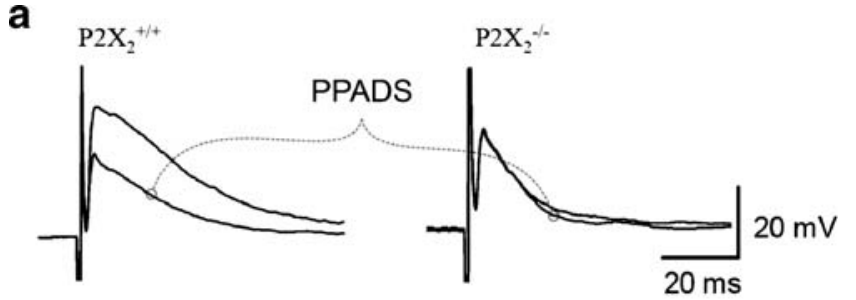

b

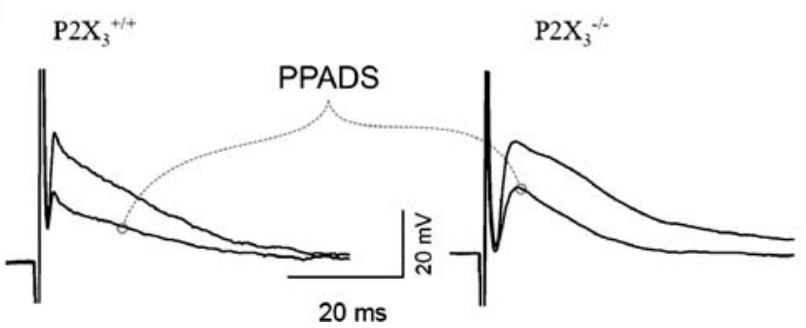

Fig. 4a, b Fast EPSPs in myenteric $S$ neurons from mice deficient in $\mathrm{P}_{2} \mathrm{X}_{2}$ (A.) or $\mathrm{P}_{2} \mathrm{X}_{3}$ (B.) receptors. a Recordings from $\mathrm{S}$ neurons in $\mathrm{P} 2 \mathrm{X}_{2}{ }^{+/+}$(left) and $\mathrm{P} 2 \mathrm{X}_{2}^{-/-}$(right) mice. The fast EPSPs recorded from neurons in tissues from $\mathrm{P}_{2} \mathrm{X}_{2}^{+/+}$mice were inhibited by PPADS $(10 \mu \mathrm{M})$ while those from neurons in $\mathrm{P} 2 \mathrm{X}_{2}{ }^{-/}$tissues were unaffected (right). b Fast EPSPs recorded from $\mathrm{S}$ neurons in $\mathrm{P} 2 \mathrm{X}_{3}{ }^{+/+}$ (left) and $\mathrm{P}_{2} \mathrm{X}_{3}^{-/-}$(right) mice; both were inhibited by PPADS $(10 \mu \mathrm{M})$. Adapted from [78, 89]. Copyright (C) Journal of Physiology 
Together, these data suggest that in guinea pig myenteric $S$ neurons, fast EPSPs are mediated by $\mathrm{P}_{2} \mathrm{X}_{3}$ subunit-containing receptors while $\mathrm{AH}$ neurons probably express $\mathrm{P} 2 \mathrm{X}_{2}$ homomers. In contrast, mouse myenteric $\mathrm{S}$ neurons express $\mathrm{P} 2 \mathrm{X}_{2}$ homomers that mediate fast synaptic transmission, and $\mathrm{AH}$ neurons express $\mathrm{P}_{2} \mathrm{X}_{3}$ subunit-containing receptors.

ATP is also a transmitter in descending excitatory reflexes [92, 93] as this pathway is sensitive to $\mathrm{P} 2 \mathrm{X}$ receptor antagonists. $\mathrm{P} 2 \mathrm{X}$ receptor-mediated fast synaptic transmission participates in descending inhibitory reflex pathways in guinea pig small intestine [17] but not in rat small intestine or guinea pig colon [94, 95] [see Chapter 2, this issue, 4]. Despite this role for $\mathrm{P} 2 \mathrm{X}$ receptors, neither the phenotype of the $\mathrm{P} 2 \mathrm{X}_{2}$ nor $\mathrm{P} 2 \mathrm{X}_{3}$ knockout mice shows any outstanding abnormality $[78,89]$. The mechanisms that maintain normal GI physiology when purinergic receptors are lost remains unclear.

\section{P2Y receptors mediate slow EPSPs in the ENS}

Slow EPSPs in the ENS are long-lasting ( $>1 \mathrm{~s})$, moderate amplitude $(\sim 5 \mathrm{mV})$ depolarizations that generally require a train of presynaptic stimuli to be evoked. The excitability of the neuron is greatly enhanced by a slow EPSP, often leading to repetitive firing of action potentials. Slow synaptic transmission within the ENS is mainly mediated by tachykinins acting at neurokinin receptors and $\mathrm{ACh}$

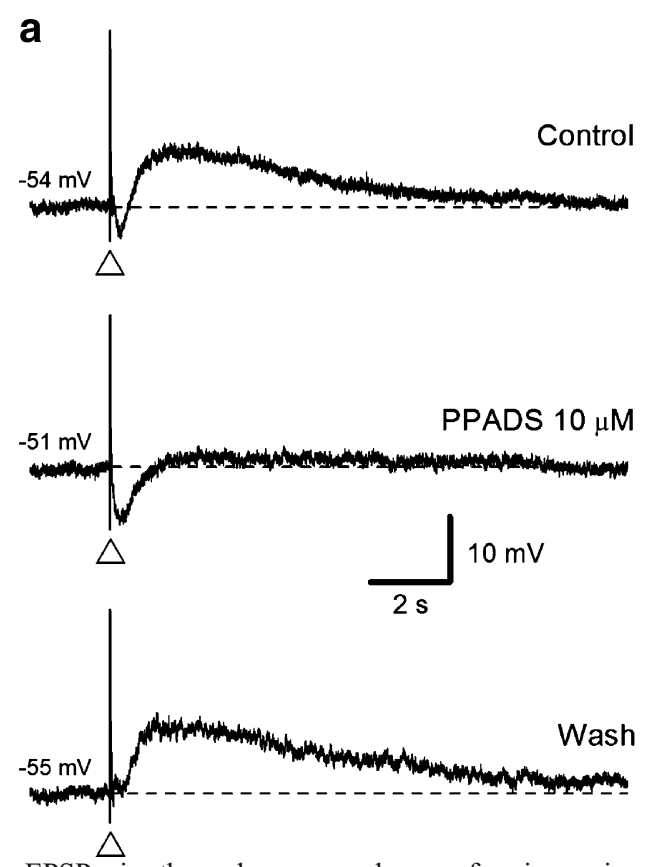

Fig. 5a, b Slow EPSPs in the submucous plexus of guinea pig ileum are blocked by P2Y receptor antagonists. Voltage traces taken from two submucosal neurons. a A single-pulse electrical stimulus evoked, in the following order: a fast EPSP, an intermediate EPSP, a small IPSP and a slow EPSP. Application of the P2-receptor antagonist PPADS $(30 \mu \mathrm{M}$, middle trace) abolished the slow EPSP. acting at muscarinic receptors. There are, however, a host of other candidates for mediators of slow EPSPs, including ATP acting at P2Y receptors.

\section{Localization of $P 2 Y$ receptors in the ENS}

Work in the mouse myenteric plexus has shown that immunoreactivity for $\mathrm{P}_{2} \mathrm{Y}_{1}$ receptors is located on NOS immunoreactive neurons (descending interneurons or inhibitory motor neurons) and that mRNA can be found in both myenteric and submucous plexes [74]. Work in the submucous plexus has suggested that neurons expressing $\mathrm{P}_{2} \mathrm{Y}_{1}$ receptors are secretomotor [20, 96]. More recently, the $\mathrm{P} 2 \mathrm{Y}_{1}$ receptor has been cloned from the guinea pig submucous plexus and characterized in human embryonic kidney cells [97], though the original neuronal class expressing the receptor was not identified. $\mathrm{P}_{2} \mathrm{Y}_{2}$ receptors have been localized to the rat colon myenteric plexus where almost a quarter of these neurons co-expressed nNOS [80]. $\mathrm{P} 2 \mathrm{Y}_{2}$ receptor immunoreactivity was also co-localized with a majority of calretinin immunoreactive neurons in the myenteric plexus (ascending interneurons and excitatory motor neurons) and all the NPY immunoreactive neurons in the submucous plexus (secretomotor neurons) [98]. Immunoreactivity for $\mathrm{P}_{2} \mathrm{Y}_{6}$ receptors was found in all regions of the guinea pig gastrointestinal tract in the myenteric plexus, but not the submucous plexus [99]. About $32 \%$ of $\mathrm{P}_{2} \mathrm{Y}_{6}$ receptor immunoreactivity was co-localized to NOS immu-

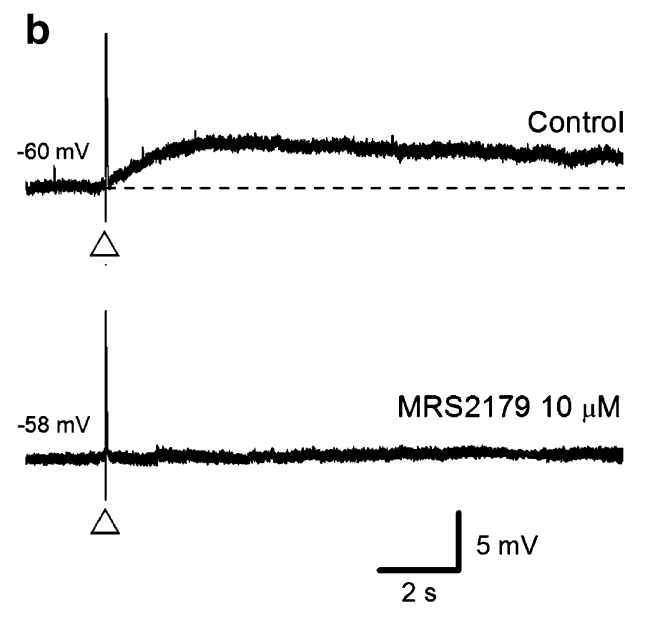

Note, the IPSP amplitude is enhanced in the middle trace by the blockade of the intermediate EPSP and the slow EPSP. b The selective $\mathrm{P}_{2} \mathrm{Y}_{1}$-receptor antagonist MRS $2179(10 \mu \mathrm{M})$ abolished the slow EPSP while the fast EPSP was spared. The IPSP in this cell had already been blocked with idazoxan. Adapted from [19]. Copyright $(C$ Journal of Physiology 
noreactive neurons (descending interneurons and inhibitory motor neurons) and about $45 \%$ to calretinin immunoreactive neurons (ascending interneurons and excitatory motor neurons). In the guinea pig small intestine, the $\mathrm{P}_{2} \mathrm{Y}_{12}$ receptor has been localized to calbindin immunoreactive neurons (AH/sensory neurons) [99], while in the rat colon, $\mathrm{P}_{2} \mathrm{Y}_{12}$ receptors have been localized to the myenteric plexus [80].

\section{Properties of $P 2 Y$ receptors in the ENS}

Christofi et al. [35] looked at cultured myenteric neurons from guinea pig and showed that there is a rise in intracellular calcium associated with application of ATP and activation of $\mathrm{P} 2$ receptors. This was confirmed in submucosal neurons where a fast $\mathrm{P} 2 \mathrm{X}$ receptor-mediated and a slow $\mathrm{P} 2 \mathrm{Y}$ receptor-mediated calcium rise and depolarization were identified [100]. In contrast, a rise in calcium in the intrinsic sensory neurons can activate the potassium conductance underlying the AHP. In submucous neurons, the $\mathrm{P} 2 \mathrm{Y}_{1}$ receptor has been linked to mobilization of $\mathrm{Ca}^{2+}$ from intracellular stores by activation of phospholipase $C$ and synthesis of inositol 1,4,5-trisphosphate with the subsequent depolarization associated with a conductance increase [20].

\section{Slow synaptic transmission}

In the guinea pig ileum myenteric plexus, electrophysiological recordings have shown that $\mathrm{P} 2 \mathrm{Y}$ receptors are present on $\mathrm{S}$ neurons (interneurons and motor neurons). When exogenous ATP was applied, there was a profound depolarization of the S neurons [101]. Recent work in the myenteric plexus has found that $\mathrm{S}$ neurons have distensionevoked slow EPSPs that are blocked by PPADS [102]. These slow EPSPs only occurred in NOS-positive descending interneurons [103]. These data are supported by work in the mouse demonstrating that $\mathrm{P}_{2} \mathrm{Y}_{1}$ receptors are on NOSpositive myenteric neurons [74].

Recent studies in the submucosal plexus of the guinea pig have demonstrated P2Y-mediated slow EPSPs (Fig. 5) that are blocked by the selective $\mathrm{P}_{2} \mathrm{Y}_{1}$ antagonist MRS 2179 [19, 104, 105]. Interestingly, a single-stimulus-evoked EPSP with a time course between that of a fast and a slow EPSP (an intermediate EPSP) was shown to be blocked by PPADS, suramin, and the selective $\mathrm{P}_{2} \mathrm{Y}_{1}$ receptor antagonist MRS 2179 [19]. Most submucous neurons, including most noncholinergic secretomotor neurons (VIP-IR) exhibited an intermediate EPSP that could occur spontaneously and was sometimes large enough to initiate action potentials.

Electrophysiological studies in guinea pig ileum have also shown P2Y receptors on the intrinsic sensory neurons of the myenteric plexus. Here they appear to mediate a hyperpolarization of the membrane due to an opening of the calcium-activated potassium conductance $[85,101]$. This has been supported by calcium imaging studies that suggest a P2Y receptor is coupled to release of internal calcium [35] possibly through a $\mathrm{P} 2 \mathrm{Y}_{1}$ receptor [20].

\section{Intestinal pathologies and purinergic signaling}

Changes in purinergic signaling in the ENS may contribute to some pathological mechanisms in the GI tract. Recent evidence points toward an alteration in purinergic synaptic transmission in inflamed tissue. Evoked fast EPSPs in myenteric neurons increase in amplitude following trinitrobenzene sulphonic acid (TNBS) colitis [106]. Later electrophysiological studies of submucosal neurons in guinea pig colon have shown the increase in fast EPSP amplitude could be attributed to a P2X component in inflamed tissue [65]. This fits well with earlier work on inflammatory bowel patients that showed an increase in $\mathrm{P} 2 \mathrm{X}_{3}$ immunoreactivity in the colonic enteric neurons [107]. One question that remains is what mechanism underlies the increase in purinergic fast EPSPs in inflamed tissue? Upregulation of presynaptic ATP release and/or alteration of postsynaptic P2X receptors appear to contribute in the submucous and myenteric plexes, respectively $[65,106]$. Recently this work has been extended to show that, following resolution of colitis, the increase in purinergic fast EPSP amplitude remains [108] and that there is an increase in fast EPSP amplitude in noninvolved tissue remote from the inflammation [109].

Changes in adenosine receptors have also been found in a rabbit model of chronic ileitis where an up-regulation of $A_{1}$ and $A_{3}$ receptors at the transcriptional level was found [110]. Other studies have shown that stimulation of $A_{2 A}$ receptors can reduce inflammation in the intestinal mucosa in rabbits and mice [111] and reduce tissue injury and inflammation in mice with toxin A-induced enteritis [112]. A recent study utilized a high-density oligonucleotide microarray analysis to study TNBS-induced colitis [113]. It was found that receptors for $\mathrm{P} 2 \mathrm{X}_{1,4,7}$ and $\mathrm{P} 2 \mathrm{Y}_{2,6}$ and all adenosine receptors were upregulated while there was a down regulation of $\mathrm{P} 2 \mathrm{X}_{2}$ and $\mathrm{P} 2 \mathrm{Y}_{1,4}$ receptors. Activation of $\mathrm{A}_{3}$ receptors reversed many, but not all, of the changes in gene expression due to inflammation [113].

\section{Summary and conclusions}

In the enteric nervous system, ATP plays a role as a neurotransmitter between enteric neurons while adenosine probably plays a role as a neuromodulator. The regulated release of ATP from enteric neurons has been shown to 
mediate fast synaptic potentials via $\mathrm{P}_{2} \mathrm{X}_{2}$ and $\mathrm{P} 2 \mathrm{X}_{3}$ receptors and slow synaptic potentials via $\mathrm{P}_{2} \mathrm{Y}_{1}$ receptors. The role of adenosine is as a modulator of presynaptic inhibition of transmission and acts mainly via $A_{1}$ receptors to inhibit gastrointestinal activity. Finally, both adenosine and ATP receptors have been shown to be altered during gastrointestinal pathologies. These conclusions are drawn mainly from guinea pig or rodent models, which have revealed important species differences.

A challenge for future studies will be to determine if these conclusions hold true for all mammalian species including humans. This is important as drugs targeted at purine receptors have shown promise for ameliorating some of the changes seen during gastrointestinal diseases.

Acknowledgements The authors wish to thank Dr. Rebecca L. Bertrand for helpful comments and the Department of Physiology and Cell Biology, University of Nevada School of Medicine and the School of Medical Sciences, University of New South Wales for financial support (PPB).

\section{References}

1. Furness JB, Sanger GJ (2002) Intrinsic nerve circuits of the gastrointestinal tract: identification of drug targets. Curr Opin Pharmacol 2(6):612-622

2. Galligan JJ (2002) Ligand-gated ion channels in the enteric nervous system. Neurogastroenterol Motil 14(6):611-623

3. Wood JD, Kirchgessner A (2004) Slow excitatory metabotropic signal transmission in the enteric nervous system. Neurogastroenterol Motil 16(Suppl 1):71-80

4. Bornstein JC (2006) Purinergic mechanisms in the control of gastrointestinal motility. In: Galligan JJ, Blackshaw LA (eds) Purinergic signaling in the gastrointestinal tract. Chapter 2

5. Christofi F (2006) Purinergic receptors and gastrointestinal secretomotor function. In: Galligan JJ, Blackshaw LA (eds) Purinergic signaling in the gastrointestinal tract. Chapter 3

6. Costa M, Brookes SJ, Steele PA et al (1996) Neurochemical classification of myenteric neurons in the guinea-pig ileum. Neuroscience 75:949-967

7. Furness JB, Costa M (1987) The enteric nervous system. Churchill Livingstone, New York

8. Furness JB (2000) Types of neurons in the enteric nervous system. J Auton Nerv Syst 81(1-3):87-96

9. Brookes SJ (2001) Classes of enteric nerve cells in the guineapig small intestine. Anat Rec 262(1):58-70

10. Furness JB, Kunze WA, Bertrand PP et al (1998) Intrinsic primary afferent neurons of the intestine. Prog Neurobiol 54:118

11. Hirst GD, Holman ME, Spence I (1974) Two types of neurones in the myenteric plexus of duodenum in the guinea-pig. J Physiol 236:303-326

12. Bornstein JC, Furness JB, Kunze WA (1994) Electrophysiological characterization of myenteric neurons: how do classification schemes relate? J Auton Nerv Syst 48:1-15

13. Mao Y, Wang B, Kunze W (2006) Characterization of myenteric sensory neurons in the mouse small intestine. J Neurophysiol 96 (3):998-1010

14. Pompolo S, Furness JB (1988) Ultrastructure and synaptic relationships of calbindin-reactive, Dogiel type II neurons, in myenteric ganglia of guinea-pig small intestine. J Neurocytol 17:771-782

15. Kunze WA, Bertrand PP, Furness JB et al (1997) Influence of the mucosa on the excitability of myenteric neurons. Neuroscience 76(2):619-634

16. Smith TK, Burke EP, Shuttleworth CW (1999) Topographical and electrophysiological characteristics of highly excitable S neurones in the myenteric plexus of the guinea-pig ileum. J Physiol 517(Pt 3):817-830

17. Bian X-C, Bertrand PP, Bornstein JC (2000) P2X receptors mediate synaptic transmission to inhibitory motor neurons in descending reflexes in the guinea-pig ileum. J Physiol 528 (3):551-560

18. Crist JR, He XD, Goyal RK (1992) Both ATP and the peptide VIP are inhibitory neurotransmitters in guinea-pig ileum circular muscle. J Physiol 447:119-131

19. Monro RL, Bertrand PP, Bornstein JC (2004) ATP participates in three excitatory post-synaptic potentials in the submucous plexus of the guinea pig ileum. J Physiol 556(2):571-584

20. Hu HZ, Gao N, Zhu MX et al (2003) Slow excitatory synaptic transmission mediated by $\mathrm{P} 2 \mathrm{Y} 1$ receptors in the guinea-pig enteric nervous system. J Physiol 550(Pt 2):493-504

21. Ralevic V, Burnstock G (1998) Receptors for purines and pyrimidines. Pharmacol Rev 50(3):413-492

22. Edwards FA, Gibb AJ, Colquhoun D (1992) ATP receptormediated synaptic currents in the central nervous system. Nature 359(6391):144-147

23. Evans RJ, Derkach V, Surprenant A (1992) ATP mediates fast synaptic transmission in mammalian neurons. Nature 357 (6378):503-505

24. Silinsky EM, Gerzanich V, Vanner SM (1992) ATP mediates excitatory synaptic transmission in mammalian neurones. $\mathrm{Br} \mathrm{J}$ Pharmacol 106(4):762-763

25. Christofi FL (2001) Unlocking mysteries of gut sensory transmission: is adenosine the key? News Physiol Sci 16:201207

26. Khakh BS, Burnstock G, Kennedy C et al (2001) International Union of Pharmacology. XXIV. Current status of the nomenclature and properties of $\mathrm{P} 2 \mathrm{X}$ receptors and their subunits. Pharmacol Rev 53(1):107-118

27. North RA (2002) Molecular physiology of P2X receptors. Physiol Rev 82(4):1013-1067

28. von Kugelgen I, Wetter A (2000) Molecular pharmacology of P2Y-receptors. Naunyn Schmiedebergs Arch Pharmacol 362(4 5):310-323

29. Abbracchio MP, Burnstock G, Boeynaems JM et al (2006) International Union of Pharmacology. LVIII. Update on the P2Y $\mathrm{G}$ protein-coupled nucleotide receptors: from molecular mechanisms and pathophysiology to therapy. Pharmacol Rev 58 (3):281-341

30. Roberts JA, Vial C, Digby HR et al (2006) Molecular properties of P2X receptors. Pflügers Arch 452(5):486-500

31. Humphrey PP, Khakh BS, Kennedy C et al (1998) P2X receptors. In: Girdlestone D (ed) The IUPHAR compendium of receptor characterization and classification. Burlington Press, Cambridge, UK, pp 195-208

32. Harden TK, Barnard EA, Boeynaems HM et al (1998) P2Y receptors. In: Girdlestone D (ed) The IUPHAR compendium of receptor characterization and classification. Burlington Press, Cambridge, UK, pp 209-217

33. Zimmermann H (2006) Ectonucleotidases in the nervous system. Novartis Found Symp 276:113-128

34. Nitahara K, Kittel A, Liang SD et al (1995) A1-receptormediated effect of adenosine on the release of acetylcholine from the myenteric plexus: role and localization of ecto-ATPase and 5'-nucleotidase. Neuroscience 67(1):159-168 
35. Christofi FL, Guan Z, Wood JD et al (1997) Purinergic Ca2+ signaling in myenteric neurons via P2 purinoceptors. Am J Physiol 272(3 Pt 1):G463-473

36. Kamiji T, Morita K, Katayama Y (1994) ATP regulates synaptic transmission by pre-and postsynaptic mechanisms in guinea-pig myenteric neurons. Neuroscience 59(1):165-174

37. Correia-de-Sa P, Adaes S, Timoteo MA et al (2006) Fine-tuning modulation of myenteric motoneurons by endogenous adenosine: on the role of secreted adenosine deaminase. Autonom Neurosci 126-127:211-224

38. Begg M, Dale N, Llaudet E et al (2002) Modulation of the release of endogenous adenosine by cannabinoids in the myenteric plexus-longitudinal muscle preparation of the guineapig ileum. Br J Pharmacol 137(8):1298-1304

39. Hasko G, Pacher P, Deitch EA et al (2007) Shaping of monocyte and macrophage function by adenosine receptors. Pharmacolog Ther 113:264-275

40. Deshpande NA, McDonald TJ, Cook MA (1999) Endogenous interstitial adenosine in isolated myenteric neural networks varies inversely with prevailing PO2. Am J Physiol 276(4 Pt 1):G875-G785

41. Kadowaki M, Tokita K, Nagakura Y et al (2000) Adenosine A1 receptor blockade reverses dysmotility induced by ischemiareperfusion in rat colon. Eur J Pharmacol 409(3):319-323

42. Zizzo MG, Mule F, Serio R (2006) Inhibitory responses to exogenous adenosine in murine proximal and distal colon. Br J Pharmacol 148(7):956-963

43. Woods CM, Toouli J, Saccone GT (2003) A2A and A3 receptors mediate the adenosine-induced relaxation in spontaneously active possum duodenum in vitro. $\mathrm{Br} \mathrm{J}$ Pharmacol 138 (7):1333-1339

44. Moneta NA, McDonald TJ, Cook MA (1997) Endogenous adenosine inhibits evoked substance $\mathrm{P}$ release from perifused networks of myenteric ganglia. Am J Physiol 272(1 Pt 1):G38-G45

45. Lee JJ, Talubmook C, Parsons ME (2001) Activation of presynaptic A1-receptors by endogenous adenosine inhibits acetylcholine release in the guinea-pig ileum. J Auton Pharm 21(1):29-38

46. Sun D, Samuelson LC, Yang T et al (2001) Mediation of tubuloglomerular feedback by adenosine: evidence from mice lacking adenosine 1 receptors. Proc Natl Acad Sci USA 98 (17):9983-9988

47. Kadowaki M, Nagakura Y, Tokita K et al (2003) Adenosine A1 receptor blockade reverses experimental postoperative ileus in rat colon. Eur J Pharmacol 458(1-2):197-200

48. Storr M, Thammer J, Dunkel R et al (2002) Modulatory effect of adenosine receptors on the ascending and descending neural reflex responses of rat ileum. BMC Neurosci 3:21

49. Duarte-Araujo M, Nascimento C, Alexandrina Timoteo $\mathrm{M}$ et al (2004) Dual effects of adenosine on acetylcholine release from myenteric motoneurons are mediated by junctional facilitatory A (2A) and extrajunctional inhibitory $\mathrm{A}(1)$ receptors. $\mathrm{Br} \mathrm{J}$ Pharmacol 141(6):925-934

50. Christofi FL, Zhang H, Yu JG et al (2001) Differential gene expression of adenosine $\mathrm{A} 1, \mathrm{~A} 2 \mathrm{a}, \mathrm{A} 2 \mathrm{~b}$, and $\mathrm{A} 3$ receptors in the human enteric nervous system. J Comp Neurol 439(1):46-64

51. Christofi FL, Wood JD (1994) Electrophysiological subtypes of inhibitory $\mathrm{P} 1$ purinoceptors on myenteric neurones of guinea-pig small bowel. Br J Pharmacol 113(3):703-710

52. Gao N, Hu HZ, Liu S et al (2006) Stimulation of adenosine A1 and $\mathrm{A} 2 \mathrm{~A}$ receptors by adenosine $5^{\prime}$-monophosphate (AMP) in the submucosal plexus of guinea-pig small intestine. Am J Physiol. DOI:10.1152/ajpgi.00257.2006

53. Palmer JM, Wood JD, Zafirov DH (1987) Purinergic inhibition in the small intestinal myenteric plexus of the guinea-pig. $J$ Physiol 387:357-369

54. Barajas-Lopez C, Surprenant A, North RA (1991) Adenosine A1 and $\mathrm{A} 2$ receptors mediate presynaptic inhibition and postsynaptic excitation in guinea pig submucosal neurons. J Pharmacol Exp Ther 258(2):490-495

55. Palmer JM, Wood JD, Zafirov DH (1987) Transduction of aminergic and peptidergic signals in enteric neurones of the guinea-pig. J Physiol 387:371-383

56. Wiklund NP, Gustafsson LE (1987) On the nature of endogenous purines modulating cholinergic neurotransmission in the guineapig ileum. Acta Physiol Scand 131(1):11-18

57. Broad RM, McDonald TJ, Brodin E et al (1992) Adenosine A1 receptors mediate inhibition of tachykinin release from perifused enteric nerve endings. Am J Physiol 262(3 Pt 1):G525-G531

58. Ribeiro JA, Cunha RA, Correia-de-Sa P et al (1996) Purinergic regulation of acetylcholine release. Prog Brain Res 109:231-241

59. Brouns I, Adriaensen D, Burnstock G et al (2000) Intraepithelial vagal sensory nerve terminals in rat pulmonary neuroepithelial bodies express P2X3 receptors. Am J Respir Cell Mol Biol 23 (1):52-61

60. Evans RJ, Surprenant A (1992) Vasoconstriction of guinea-pig submucosal arterioles following sympathetic nerve stimulation is mediated by the release of ATP. Br J Pharmacol 106(2):242-249

61. Kreis ME, Haupt W, Kirkup AJ et al (1998) Histamine sensitivity of mesenteric afferent nerves in the rat jejunum. Am J Physiol 275(4 Pt 1):G675-G680

62. White TD, Leslie RA (1982) Depolarization-induced release of adenosine 5 '-triphosphate from isolated varicosities derived from the myenteric plexus of the guinea pig small intestine. J Neurosci 2(2):206-215

63. White TD (1982) Release of ATP from isolated myenteric varicosities by nicotinic agonists. Eur J Pharmacol 79(3-4):333-334

64. Bertrand PP (2003) ATP and sensory transduction in the enteric nervous system. Neuroscience 9(4):243-260

65. Lomax AE, Mawe GM, Sharkey KA (2005) Synaptic facilitation and enhanced neuronal excitability in the submucosal plexus during experimental colitis in guinea-pig. J Physiol 564(Pt 3):863-875

66. Zhou X, Galligan JJ (1996) P2X purinoceptors in cultured myenteric neurons of guinea-pig small intestine. J Physiol 496 (Pt 3):719-729

67. Ren J, Galligan JJ (2007) A calcium-activated potassium conductance is coupled to $\mathrm{P} 2 \mathrm{X}$ receptors in myenteric neurons of guinea pig ileum. Neurogastroenterol Motil. DOI 10.1111/ j.1365-2982.2007.00952.x.

68. Zhou X, Galligan JJ (1998) Non-additive interaction between nicotinic cholinergic and $\mathrm{P} 2 \mathrm{X}$ purine receptors in guinea-pig enteric neurons in culture. J Physiol 513(3):685-697

69. Barajas-Lopez C, Espinosa-Luna R, Zhu Y (1998) Functional interactions between nicotinic and P2X channels in short-term cultures of guinea-pig submucosal neurons. J Physiol 513(Pt 3):671-683

70. Khakh BS, Zhou X, Sydes J et al (2000) State-dependent crossinhibition between transmitter-gated cation channels. Nature 406 (6794):405-410

71. Barajas-Lopez C, Montano LM, Espinosa-Luna R (2002) Inhibitory interactions between 5-HT3 and P2X channels in submucosal neurons. Am J Physiol 283(6):G1238-G1248

72. Karanjia R, Garcia-Hernandez LM, Miranda-Morales $M$ et al (2006) Cross-inhibitory interactions between GABAA and P2X channels in myenteric neurones. Eur J Neurosci 23(12):3259-3268

73. Castelucci P, Robbins HL, Poole DP et al (2002) The distribution of purine $\mathrm{P} 2 \mathrm{X}(2)$ receptors in the guinea-pig enteric nervous system. Histochem Cell Biol 117(5):415-422

74. Giaroni C, Knight GE, Ruan HZ et al (2002) P2 receptors in the murine gastrointestinal tract. Neuropharmacology 43(8):1313-1323

75. Poole DP, Castelucci P, Robbins HL et al (2002) The distribution of P2X3 purine receptor subunits in the guinea pig enteric nervous system. Autonom Neurosci 101(1-2):39-47 
76. Van Nassauw L, Brouns I, Adriaensen D et al (2002) Neurochemical identification of enteric neurons expressing P2X(3) receptors in the guinea-pig ileum. Histochem Cell Biol 118(3):193-203

77. Ruan HZ, Burnstock G (2005) The distribution of P2X5 purinergic receptors in the enteric nervous system of mouse. Cell Tissue Res 319(2):191-200

78. Ren J, Bian X, DeVries M et al (2003) P2X2 subunits contribute to fast synaptic excitation in myenteric neurons of the mouse small intestine. J Physiol 552(Pt 3):809-821

79. Xiang Z, Burnstock G (2004) P2X2 and P2X3 purinoceptors in the rat enteric nervous system. Histochem Cell Biol 121(3):169-179

80. Van Crombruggen K, Van Nassauw L, Timmermans JP et al (2007) Inhibitory purinergic P2 receptor characterisation in rat distal colon. Neuropharmacology 53(2):257-271

81. Galligan JJ, Bertrand PP (1994) ATP mediates fast synaptic potentials in enteric neurons. J Neurosci 14:7563-7571

82. LePard KJ, Messori E, Galligan JJ (1997) Purinergic fast excitatory postsynaptic potentials in myenteric neurons of guinea pig: distribution and pharmacology. Gastroenterology 113(5):1522-1534

83. Nurgali K, Furness JB, Stebbing MJ (2003) Analysis of purinergic and cholinergic fast synaptic transmission to identified myenteric neurons. Neuroscience 116(2):335-347

84. LePard KJ, Galligan JJ (1999) Analysis of fast synaptic pathways in myenteric plexus of guinea pig ileum. Am J Physiol 276(2 Pt 1):G529-G538

85. Bertrand PP, Bornstein JC (2002) ATP as a putative sensory mediator: activation of intrinsic sensory neurons of the myenteric plexus via P2X receptors. J Neurosci 22(12):4767-4775

86. Nurgali K, Furness JB, Stebbing MJ (2003) Correlation of electrophysiology, shape and synaptic properties of myenteric $\mathrm{AH}$ neurons of the guinea pig distal colon. Autonom Neurosci 103(1-2):50-64

87. Furukawa K, Taylor GS, Bywater RA (1986) An intracellular study of myenteric neurons in the mouse colon. J Neurophysiol 55(6):1395-1406

88. Tamura K, Ito H, Wade PR (2001) Morphology, electrophysiology, and calbindin immunoreactivity of myenteric neurons in the guinea pig distal colon. J Comp Neurol 437(4):423-437

89. Bian X, Ren J, DeVries M et al (2003) Peristalsis is impaired in the small intestine of mice lacking the P2X3 subunit. J Physiol 551(Pt 1):309-322

90. Lewis C, Neidhart S, Holy C et al (1995) Coexpression of P2X2 and $\mathrm{P} 2 \mathrm{X} 3$ receptor subunits can account for ATP-gated currents in sensory neurons. Nature 377(6548):432-435

91. Xiang Z, Burnstock G (2004) Development of nerves expressing $\mathrm{P} 2 \mathrm{X} 3$ receptors in the myenteric plexus of rat stomach. Histochem Cell Biol 122(2):111-119

92. Spencer NJ, Walsh M, Smith TK (2000) Purinergic and cholinergic neuro-neuronal transmission underlying reflexes activated by mucosal stimulation in the isolated guinea-pig ileum. J Physiol 522(2):321-331

93. Monro RL, Bertrand PP, Bornstein JC (2002) ATP and 5-HT are principal neurotransmitters in the descending excitatory reflex pathway of the guinea-pig ileum. Neurogastroenterol Motil 14 (3):255-264

94. Bian XC, Heffer LF, Gwynne RM et al (2004) Synaptic transmission in simple motility reflex pathways excited by distension in guinea pig distal colon. Am J Physiol 287(5): G1017-G1027

95. Bian X-C, Bornstein JC, Bertrand PP (2003) Nicotinic transmission at functionally distinct synapses in descending reflex pathways of the rat colon. Neurogastroenterol Motil 15(2):161-171

96. Fang $\mathrm{X}, \mathrm{Hu} \mathrm{HZ}$, Gao $\mathrm{N}$ et al (2006) Neurogenic secretion mediated by the purinergic $\mathrm{P} 2 \mathrm{Y} 1$ receptor in guinea-pig small intestine. Eur J Pharmacol 536(1-2):113-122
97. Gao N, Hu HZ, Zhu MX et al (2006) The P2Y purinergic receptor expressed by enteric neurones in guinea-pig intestine. Neurogastroenterol Motil 18(4):316-323

98. Xiang Z, Burnstock G (2005) Distribution of P2Y2 receptors in the guinea pig enteric nervous system and its coexistence with $\mathrm{P} 2 \mathrm{X} 2$ and $\mathrm{P} 2 \mathrm{X} 3$ receptors, neuropeptide $\mathrm{Y}$, nitric oxide synthase and calretinin. Histochem Cell Biol 124(5):379-390

99. Xiang Z, Burnstock G (2006) Distribution of P2Y(6) and P2Y (12) receptor: their colocalization with calbindin, calretinin and nitric oxide synthase in the guinea pig enteric nervous system. Histochem Cell Biol 125(4):327-336

100. Barajas-Lopez C, Espinosa-Luna R, Christofi FL (2000) Changes in intracellular $\mathrm{Ca} 2+$ by activation of $\mathrm{P} 2$ receptors in submucosal neurons in short-term cultures. Eur J Pharmacol 409(3):243-257

101. Katayama Y, Morita K (1989) Adenosine 5'-triphosphate modulates membrane potassium conductance in guinea-pig myenteric neurones. J Physiol 408:373-390

102. Bornstein JC, Thornton PD, Gwynne RM (2002) ATP acting on $\mathrm{P} 2 \mathrm{Y}$ receptor mediates synaptic transmission between interneurons of the descending inhibitory reflex pathway in guinea pig ileum. Gastroenterology 122(Suppl):A8

103. Thornton PD, Bornstein JC (2002) Slow excitatory synaptic potentials evoked by distension in myenteric descending interneurones of guinea-pig ileum. J Physiol 539(Pt 2):589-602

104. Hu H-Z, Gao N, Zhu M et al (2002) Purinergic slow excitatory synpatic transmission in guinea pig small intestinal submucous plexus. Gastroenterology 122(Suppl):A8

105. Nandanan E, Camaioni E, Jang SY et al (1999) Structure-activity relationships of bisphosphate nucleotide derivatives as $\mathrm{P} 2 \mathrm{Y} 1$ receptor antagonists and partial agonists. J Med Chem 42 (9): $1625-1638$

106. Linden DR, Sharkey KA, Mawe GM (2003) Enhanced excitability of myenteric $\mathrm{AH}$ neurones in the inflamed guinea-pig distal colon. J Physiol 547(2):589-601

107. Yiangou Y, Facer P, Baecker PA et al (2001) ATP-gated ion channel $\mathrm{P} 2 \mathrm{X}(3)$ is increased in human inflammatory bowel disease. Neurogastroenterol Motil 13(4):365-369

108. Lomax AE, O'Hara JR, Hyland NP et al (2006) Persistent alterations to enteric neural signalling in guinea pig colon following resolution of colitis. Am J Physiol. DOI 10.1152/ ajpgi.00355.2006

109. O'Hara JR, Lomax AE, Mawe GM et al (2006) Ileitis alters neuronal and enteroendocrine signalling in guinea-pig distal colon. Gut. DOI 10.1136/gut.2006.102780

110. Sundaram U, Hassanain H, Suntres $Z$ et al (2003) Rabbit chronic ileitis leads to up-regulation of adenosine A1/A3 gene products, oxidative stress, and immune modulation. Biochem Pharmacol 65(9):1529-1538

111. Odashima M, Bamias G, Rivera-Nieves J et al (2005) Activation of $\mathrm{A} 2 \mathrm{~A}$ adenosine receptor attenuates intestinal inflammation in animal models of inflammatory bowel disease. Gastroenterology 129(1):26-33

112. Cavalcante IC, Castro MV, Barreto AR et al (2006) Effect of novel A2A adenosine receptor agonist ATL 313 on Clostridium difficile toxin A-induced murine ileal enteritis. Infect Immun 74 (5):2606-2612

113. Guzman J, Yu JG, Suntres $Z$ et al (2006) ADOA3R as a therapeutic target in experimental colitis: proof by validated high-density oligonucleotide microarray analysis. Inflamm Bowel Dis 12(8):766-789

114. Christofi FL, Wood JD (1993) Presynaptic inhibition by adenosine A1 receptors on guinea pig small intestinal myenteric neurons. Gastroenterology 104(5):1420-1429

115. Galligan JJ, LePard KJ, Schneider DA et al (2000) Multiple mechanisms of fast excitatory synaptic transmission in the enteric nervous system. J Auton Nerv Syst 81(1-3):97-103 